\title{
Public Administrators in the Europeanization of Risk Governance - Co-Creation Amidst the Political Heterarchy
}

Jeremias Herberg (jeremias.herberg@iass-potsdam.de)

Institute of Advanced Sustainability Studies e.V. (IASS), Germany

This article depicts a dialectic relationship between the creative conduct of public administrators on the one hand, and the institutional complexity of their political surrounding, on the other. An ethnographic study of the collaborative policy design of the Dutch predecessor of REACH ('Regulation for Registration, Evaluation, Authorisation and Restriction of Chemicals'), so-called SOMS (Dutch: Strategy dealing with substances), shows how risk governance policies are created, or even co-created against the backdrop of Europeanization. This creativity is depicted and operationalized through the notions of articulation work (Strauss, 1988), mobility work (Bardram and Bossen, 2005) and mutual monitoring (Heath and Luff, 1992). Dutch public administrators engaged heavily in European negotiations, thus operating amidst contradictory hierarchies and juggling with several evaluative criteria. Eventually, in 2007, this trajectory led to what some call the European Commission's most complex bill (Rettman, 2007). The Europeanization of risk governance is characterized as a process in which hierarchies are primarily not steepened or overcome, but rather multiplied and recombined into contradictory value systems and conflictual policy constellations. The paper therefore argues that Europeanization creates a political heterarchy, in which the creativity of policy-makers plays a pivotal, but paradoxical role.

Keywords: Europeanization, risk governance, co-creation, heterarchy, SOMS, REACH, soft law making, collaborative policy design

This article ${ }^{1}$ depicts a dialectic relationship between the creative conduct of public administrators on the one hand, and the institutional complexity of their political surrounding, on the other. An empirical study of the collaborative design of risk governance policies shows their creation against the backdrop of Europeanization. Europeanization is re-

\footnotetext{
${ }^{1}$ The article re-interprets the empirical work conducted during a master thesis at Maastricht University. I am most grateful to Jessica Mesman for her guidance and support. I would like to thank policy makers at the Dutch Ministry for the Environment whose insightful accounts form an inspiring and challenging ground for analysis and reflection. The article benefited greatly from comments by Dirk von Schneidemesser, from the collaboration with Dorota Stasiak, Giulia Molinengo, Daniel Oppold and Tom Bruhn at IASS Potsdam, and from discussions with Gregor Schmieg and with Benjamin Peters at Leuphana University Luneburg. Finally, I would like to thank Paul Jerchel for his assistance.
} 
characterized as a process in which hierarchies are primarily not steepened or overcome, but multiplied and recombined into contradictory value systems and conflictual policy constellations. The paper, while focusing on policy-making practice, argues that the Europeanization of risk governance can be seen as a heterarchization. That is, contradictory hierarchies are recombined and decentralized. The interviewed policy-makers navigate this confusing context not by unravelling, but by leveraging the institutional mishmash for their own strategic gain.

The described heterarchy is anchored in three aspects of policy-making practice. First, the article investigates an arguably heterarchic domain of policy-making. In risk governance, critical goals such as creating public trust and community resilience ask for twoway communication and non-linear policy strategies, thus decentralizing the instrumental rationalities that conventionally dominate public policy-making (Booher and Innes, 2010; Wynne, 2006). Second, the article scrutinizes a legal framework that was intended as a redistribution of responsibilities: the legislation called 'Regulation for Registration, Evaluation, Authorization and Restriction of Chemicals,' in short REACH. REACH holds industries accountable for the documentation and assessment of the use of risky substances. In the making of REACH, which is traced in this paper, the legislation ended up as one of the largest and most complex legislations of the European Union. Interviews with Dutch public administrators involved give a counterintuitive insight into a creative 'phase 0 ' that led up to REACH. They conceived of the process as a largely creative process. Third, the article focuses on 'co-creation' as one the recent debates in collaborative governance (Ind and Coates, 2013). Co-creation basically denotes a collectivization of administrative creativity. This at times descriptive, at times prescriptive, term, is used to call for an inclusive involvement of non-governmental groups in policy design.

These three pillars beg the question of how the creative conduct of public administrators and their complex surrounding can be interrelated in thinking and reconciled in practice. As a response it is argued that co-creative practices do not disentangle, but complicate the political heterarchy.

Section 1 discusses the key concepts, the case study and broader motivation of the article. Section 2 describes the (co-)creative process reaching from SOMS to REACH. Section 3 discusses the learnings with regard to co-creation and the political heterarchy. Section 4 provides a conclusion.

\section{Heterarchy and Creativity}

Europeanization does not simply add a hierarchical level to nation state policy-making (cf. Bach, 2008; Lepsius, 2000). It simultaneously entails vertical integration, often operating in a boundary-spanning and network-oriented way (Büttner and Mau, 2014). The following sections argue that the resulting structure is best called 'a political heterarchy'. They present the political context, the case study and the two key terms of the paper.

\subsection{EU as Heterarchy, REACH as an Exemplary Case}

The concept of heterarchy goes back to the neurologist Warren McCulloch. With the purpose of simulating the neurological process of choice-making, McCulloch modelled a network of contradictory logics of valuation. Heterarchies are not the opposite of hierarchies, but their multiplication into several decision logics, thus resulting into the paradox of parallel hierarchies. As a result, not only McCulloch's nervous system model, but social actors amidst political heterarchies find themselves not only amidst interdependent paths of action, or actors; they also juggle contradictory registers of evaluation. In short, as economic sociologist David Stark has it, "heterarchies create wealth by inviting more than one way of evaluating worth." (Stark, 2001: 14). In social conduct, heterarchies trig- 
ger creative practice. “(...) The interacting overlap of multiple performance criteria (...) generates productive recombinations by sustaining a pragmatic organizational reflexivity" (Stark, 2011: 27). On closer scrutiny, even supposedly hierarchical systems such as the Soviet command economy, as Benjamin Peters' historical work highlights, are underpinned by a "dynamic networks of competing actors" in administrative practice (Peters, 2016: 18).

To what extent is Europeanization a process of heterarchization? Erik Oddvar Eriksen already chose this terminology when he describes that "political authority is not centralized as in the hierarchical order of the state model nor is it decentralized as in an anarchical order." Instead, "law-making and law enforcement take place within a structure that combines hierarchical and horizontal procedures" (2007: 28). Europeanization thus is a process characterized by parallel hierarchies without a clear mediating hierarchy. This paradox, as this article shows, is not only a challenge for democratic institutions (Eriksen, 2007), for their role with respect to functionally differentiated societies (Brunkhorst, 1999), or for the Europeanization of professional fields (Büttner and Mau, 2014). It directly challenges the practice of public administrators on the national level, a challenge that cannot be captured by normative notions of deliberative policy-making alone.

So far, political heterarchies are mostly discussed in a structuralist or normative light. Both viewpoints stress the dialogical and reflexive feature of policy-making. The notion of dialogue can not only be seen as a normative, but also as a structural feature. Bob Jessop (2002) points in that direction when saying that coordination in a political heterarchy is dialogical, not market- or state-driven. Such coordination comprises of a reflexive rationale and negotiated success criteria. In his view, the process of Europeanization multiplies functional differentiation, spatial scales, temporal dimensions, diffuse boundaries, and the heterogeneity of identities (ibid.: 230). The consequence is a reflexive awareness of coordination problems. As Hauke Brunkhorst (1999) notes in a chapter on heterarchy and democracy, heterarchic states primarily deal with the decision premises while material decisions are assigned to the interplay of autonomous systems. Or as Lepsius has it, "(A)s soon as the number and heterogeneity of rationality criteria for EU policy increase (...), then complicated problems of mediation and balancing arise". It becomes difficult, he says, to even "specify the areas to which rationality criteria, each with their own functional logic extending into various policy areas, apply" (Lepsius, 2000: 5). This more structuralist viewpoint puts into question the normative and practical consequence. Policy levels, decentral nodes of decision-making, and contradictory normative underpinnings can for instance result into a puzzling dynamic of acceleration and deceleration (Schmieg et al., 2017). Yet, what about policy-making in practice?

Possibly such heterarchies are the structural backbone of what some call "reflexive governance" (Rip, 2006; Voß und Bornemann, 2011). Eriksen correspondingly suggests that in Europeanization we are increasingly confronted with "a regime (...) based on shared authority, and the major task is not 'redistribution', but 'regulation' of social and political risks" (2007: 5). He thus assumes that the European Union goes beyond the bureaucratic and democratic notion of a hierarchical state. Eriksen continues: "Hence the prevalence of governance and not political rule through responsible institutions such as parliament and bureaucracy" (2007: 3). From a normative standpoint, political heterarchies seem highly ambivalent. In the distinction from hierarchical rule, division of labor and democratic accountability on the one hand, political heterarchies open policies to a heterogeneous field of influence, on the other; they may foster a re-combinatory creativity across policy sectors. However, Brunkhorst and Eriksen also see heterarchies as vulnerability in both democratic and bureaucratic principles of law-making. Authority is not clearly distributed, tasks and projects cut across institutional boundaries, and decisions are not 
derived from citizens' rights. "Die Heterarchie des Rechts ist eine Herrschaft ohne Herrscher, aber keine Herrschaft des Gesetzes" (Brunkhorst, 1999: 382).

Before the structural observation of a political heterarchy can be translated into a normative governance standpoint, policy-making practices need further scrutiny (cf. Smismans, 2008). One policy arena that is characterized both by heterarchic structures and normative reflexivity is risk governance. Lofstedt et al. (2011) characterize three defining features in risk governance that are analogous to the structural observations above: there is "(...) greater public and stakeholder participation in the policy-making process". Risk regulation "calls for regulatory strategies to be completely open and transparent and for regulators to be accountable for any policy they propose." Further, "(t)he role of science is less important, as scientists are seen as just one of many stakeholders" (Lofstedt et al., 2011: 410). Along more normative lines, Ortwin Renn and Marjolein van Asselt agree with reflexive governance scholars in stating a few dominant features of risk governance: the political inclusion of various actors, the integration of various sorts of knowledges and experiences, the integration of the various phases of policy processes and a constant reflection on the given state-of-the-art in a respective policy issue, are presented as normative guiding principles (Van Asselt and Renn, 2011).

According to these authors, social hierarchies, evaluation criteria, and actor interdependencies in risk governance are recombined within a political heterarchy. Public administrators are thus required to involve a greater diversity of social actors. Moreover, they temporally face the double expectation for government officials to act early and, at the same time, reflect cautiously on those actions. Such diverging actor constellations and value systems cannot be logically reconciled, but only dealt with over time. Or in other words, the conceptualization, implementation and correction of one's policy ideas take place in the same process. This likely gives way to a practice of improvisation - thus "(c)omposing on the spur of the moment" (Schuller, 1968: 378 cited in Weick, 1998: 544). This suggests a direct link between policy structures and policy practice: Provisional politics, which implies proactive monitoring and intervention, might lead to improvising practice.

\subsection{The (II)legitimacy of Creativity and Co-creation}

While political heterarchies seem to enjoy great legitimacy among governance scholars, the implied creativity does not receive much attention, let alone legitimacy. It is, however, an intricate part of public administration, as Max Weber already noted. Creativity is necessary in the constant invention, interpretation and re-adjustment of laws and rules. Weber writes,

"Und vollends pflegt man gerade für das Gebiet der eigentlichen Verwaltungstätigkeit - d.h. für alle staatliche Tätigkeit, die nicht in das Gebiet der Rechtsschöpfung und Rechtsfindung fällt - die Freiheit und Herrschaft des Individuellen in Anspruch zu nehmen, der gegenüber die generellen Normen überwiegend als Schranken der positiven, niemals zu reglementierenden "schöpferischen“ Betätigung des Beamten eine negative Rolle spielten. Die Tragweite dieser These möge hier dahingestellt sein. Das Entscheidende bliebe doch: daß diese "frei“ schaffende Verwaltung (und eventuell: Rechtsprechung) nicht, wie wir das bei den vorbürokratischen Formen finden werden, ein Reich der freien Willkür und Gnade, der persönlich motivierten Gunst und Bewertung bilden würde. Sondern daß stets als Norm des Verhaltens die Herrschaft und rationale Abwägung „sachlicher" Zwecke und die Hingabe an sie besteht." (Sic; Weber, 2006: 1069)

The specificity of administrative creativity in modern societies according to Max Weber always involves the navigation of a more rigid system of command and control. Weber's 
perspective assigns a primarily safeguarding function to creativity, stressing how means and ends are rationally evaluated. While the material creativity that relates to a given legislation or policy problem is tantamount, the social creativity of dealing with organizational setups or diverging expectations is delegitimized in modern societies. Public administrators act as "creative copers", to use Ban's terminology, and creativity is required, but simultaneously banished by the confines of a complex legal apparatus (Ban, 1995). Noordegraaf's participant observation, however, has revealed that the social creativity of strategic passivity and strategies of avoidance seem just as pivotal, and is intricately involved in the design of new legislation (Noordegraaf, 2007). Can public administration be more intentionally, or even legitimately creative?

An affirmative view on creativity, which thus far represents a tacit undercurrent in public administration thought, is gaining shape in the course of a recent debate about so-called co-creation (Ind and Coates, 2013: 92). Co-creation explicates tacit creativities in policymaking, but also socializes them in the sense of involving the heterogeneous collectives most affected by the eventual policy. It is often legitimized as an effective response to institutional 'silos' - that is, to a bureaucratic division of labor in policy-making.

From a sociological viewpoint, co-creation is a practical and reflexive inquiry into the processual interplay of the policy subject and policy object, the creator and the created. By contrast to a more bifurcated understanding, the problem at hand and the various policy perspectives are entwined. As a result, you may pose sociological questions in a practical vein: How do collaborating collectives shape the designed policy? Or, how does the shared object help to convene otherwise disconnected groups? These questions implicate three definitional dimensions:

- In a social dimension, co-creation describes the interaction among a heterogeneous group of actors that is based on a reciprocity of exchange.

- In a material dimension, co-creation describes how the interaction of various, even conflicting perspectives triggers the generation of something unexpected that the actors involved can contribute to, acknowledge, or use.

- In a temporal or spatial dimension, co-creation describes processes or spaces in between relatively autonomous organizations or fields that enable a reciprocal exchange, and a creation of collective object(ive)s.

The discussion on co-creation hence also represents a debate about the entwinement of social, material and even spatiotemporal creativity in policy-making. Co-creation, while often juxtaposed to hierarchies, points to a more elemental and purposeful integration of the constitutive elements of a heterarchic political order. Along these lines, a popular view already triangulates co-creation and political heterarchies. It holds that complex problems, or "wicked problems" (Rittel and Webber, 1972), are best dealt with in a deliberative way (Eriksen, 2007). However, this viewpoint still sees co-creation through the light of a bifurcated relationship between policy subject and policy object. Co-creation is presented as the practical flipside of political heterarchies. Problems are not subdivided into policy sectors, thus spawning the modern conception of a functionally differentiated and hierarchical state. Rather, they are allegedly tackled on a holistic style of thought, on an inventive spirit of solution-orientation and based on a broad social collective. Does this deliberative and somewhat orderly perspective on policy-making creativity capture the messiness of public administrative practice?

\subsection{Operationalizing Co-Creation: Articulation Work, Mobility Work and Mutual Moni- toring}

Other professional domains have been studied more extensively with regard to creative practices amidst formal regulations. In hospitals or traffic control rooms, for instance, scholars have conducted ethnographic research on how material and social creativities 
interrelate in maintaining the stability of an organizational system (Bardram and Bossen, 2005; Christian Heath and Luff, 1992; Hindmarsh and Pilnick, 2002; Mesman, 2012; Suchman, 1997). Despite the highly technological, standardized and risky nature of the knowledge and technology-intensive work occupations that are studied in this field, researchers identified three concepts in particular: articulation work, mobility work and mutual monitoring are notions that may also capture how policy subjects and policy objects are entwined in the creative act of shaping a policy in the making.

As a founding scholar in this school of thought, American sociologist and pragmatist thinker Anselm Strauss called the managerial task of facilitating a project articulation work. This notion refers "to the specific details of putting together tasks, task sequences, task clusters, and even the work done in aligning larger units such as subprojects, in order to accomplish the work" (Strauss, 1988, p: 174). Using the example of safety activities of nurses, Jessica Mesman has argued that this concept also captures more informal ways of supervision and delegation, for instance the coordinative work which is necessary during unexpected events (Mesman, 2012: 6). Thus, articulation work coins the preparatory and ongoing coordination of separate lines of action enabling the collaboration on a project regarding both social and material aspects.

Mobility work captures a spatial supplement to articulation work. Bardram and Bossen (2005) came up with the term in an ethnographic study on collaboration in hospitals. It simply pinpoints the work that is done to achieve the "right configuration of people, resources, knowledge and place", which allows the personnel to carry out particular tasks, for instance a surgical operation (Bardram and Bossen, 2005: 189). Of course, to determine what is the right configuration depends on the situation at hand and, after all, might not be that simple in case of public administration.

Mutual monitoring as a third term was established in an ethnographic study conducted in the control rooms of the London Underground. Heath and Luff have identified an almost intimate interrelation between the controllers: They do "not only 'oversee' each other's actions, but monitor various events both for themselves and for the other(s); drawing, where necessary a colleague's attention to some 'matter at hand'. (Heath and Luff, 1992: 85) This term refers to moments when single collaborators support each other as early warning systems and, as the collaboration goes on, maintain an intimate relationship of mutual observation and adaptation. As Heath and Luff elaborate, they do so to redistribute or preserve task divisions as well as balance and complement each other's actions and specialized skills (ibid.). This is not merely a question of verbal negotiation, but also of monitoring each other's physical behavior (Hindmarsh and Pilnick, 2002).

\subsection{The method}

I conducted six expert interviews of between 45 and 90 minutes in duration. Five interviews were face to face, one took place via telephone. Besides four administrators of the directorate of chemical risks in the Dutch environmental ministry, I interviewed one representative each of the NGO's (Mark Veld from the foundation 'Natuur and Milieu') - and the industries (Henk Kunst from NVZ; Nederlandse Vereniging van Zeepfabrikanten representing the soap industries). As a key benefit from these interviewing choices, all interviewed administrators are - or once were - part of the same team at the department for substances and standardization at the ministry of environment. Their names are changed to protect their privacy.

In the analytical process, the Grounded Theory (GT) approach shapes data collection and interpretation. It characteristically requires the analyst to mutually adapt both aspects. In GT the researcher is aiming at a theoretical model, a "coding paradigm". The process of coding implies gathering information material and applying close-fit notions on distinct 
bits of information. During the interview process, I characterized several key issues, e.g. 'challenge of constant change' or 'bureaucracy vs. informal capacity' and drew an entire landscape of concepts and actions (140 codes in total). Afterwards I interrelated all codes in order to draft a narrative which explains the previously circumscribed phenomenon (selective coding).

\section{The case of SOMS/REACH - Co-Creation Amidst the Political Heterarchy}

REACH is an EU regulation of chemical substances entirely in effect since 1 June 2008. It can be seen as a regulation of decision premises. Conclusively, it is short for 'Regulation for Registration, Evaluation, Authorisation and Restriction of Chemicals'. SOMS, short for 'Strategie Omgaan met Stoffen' (Dutch: Strategy dealing with substances) is usually seen as its Dutch predecessor.

The policy premise of both programs is similar: Prior to SOMS and REACH, there was a perceived lack of transparency and even lack of information on the risks inherent in produced and imported chemical substances. The government, along the lines of a more hierarchical structure, was responsible for regulative measure. Yet, in the course of chemical production becoming more complex, the government became increasingly dependent on the industries' capacity and willingness to provide risk information (Interview Meertens; cf. Haverland, 2008, p: 33). Both SOMS and REACH are intended to tackle this lack of knowledge, transparency and responsibility.

More fundamentally, both policies are underpinned by a heterarchic policy structure. They are presented as a "paradigm shift" (Fuhr and Bizer, 2007) obligating chemical companies to take responsibility for risk information, assessment and the management of potentially dangerous substances themselves (Ministerie van VROM, 2004). As the related buzzword of "no data, no market" implies, substances are only allowed on the (nowadays European) market when sufficient risk information gives the all-clear. Additionally, especially those substances which may have irreducible dangers - the so-called no regret substances - are not governed on basis of their likelihood but on basis of their intrinsic, partly unknown hazards. Ironically, no regret substances are also the most promising for chemical production due to the same chemical features that make them potentially dangerous (Interview Meertens). Thus, you may address these policies as particularly cautious risk regulations - the European Comission even proposed REACH as an exemplary application of the precautionary principle (also see Tweede Kamer, 2009a: 7). This reflexive shift in risk governance also characterizes the functioning of the investigated policy. According to the interviews, the administrators' main regulatory idea in SOMS was to monitor and regulate only those substances and risks which have been identified as particularly urgent on the basis of a previously crafted substance profile. This idea, which the Dutch administrators later contributed to European negotiations, is coined as 'Quick Scans'. Quick scans were intended as a form of prioritization during risk assessment in order to efficiently identify and quickly regulate particularly risky substances. They entail that the government focuses on regulating the most urgent risks, while the industries would be accountable for the other substances as well as for the documentation, monitoring and regulatory judgment on risky substances.

Using the three ethnographic concepts, the next section shows that the administrative practitioners involved in SOMS/REACH are willfully nurturing the complexity of the problems at hand. Yet simultaneously, the creative process is at risk of being killed by its own offspring. 


\subsection{Phase Zero: Articulation Work and the First Hurdle}

In hindsight, SOMS can be described as the stage zero to REACH. It took shape earlier in 1998 when the Dutch government, industries and environmental NGO's - henceforth called the SOMS troika - decided on an assessment and regulation of previously nonassessed chemicals. This was an initiative particularly launched by the public administrators of the former Ministry of Housing, Spatial Planning and the Environment (VROM; especially Peter Meijer, Brouwer, Peters).

SOMS was an attempt to install a flexible covenant between government and industries instead of fixed legislation. This would allow both parties to establish the previously nonexisting transparency and communication channels as well as agree quickly on the steps to be taken in case unexpected risk issues occur. Also, the risk communication and knowledge exchange concerning the policy's efficiency would be more continuous than in top-down lawmaking. After all, the Dutch administration by then depended on transparent insight as well as the chemical experts in the industries, who clearly outnumber academic or governmental expertise. The flexibility of the covenant also was supposed to give smaller, less-equipped companies the time to implement a 'cultural turn' in substance regulation. By contrast, any immediate legislation would benefit larger companies that can afford lobbying, thus proactive adaptation, as well as abrupt organizational changes in preparation of an upcoming law (Interview Peters).

The creation of SOMS largely rests on "articulation work". That is, it entails the neat identification of a problem worth solving and, simultaneously, the creation of vigorous alliances. With respect to the external collaborations, the crafty identification of problems is reflected most drastically in the words of Peter Meijer. At an early consultation of various stakeholders of chemical policy-making he disclosed a presumably well-defined policy problem to the conference audience, which his minister had previously assigned to him:

"It says that there is a problem, but maybe it is not a problem at all. I'd like to hear from you if there is a problem and how you look at it. And, if there is a problem, what the solution should look like in your opinion. After all, I cannot exclude that it is not a problem.' Well, you cannot take a more vulnerable position than that as a policy-maker. First, the audience didn't know what to do. What is going on here? (...) At the end of that day, we went apart. Not that I wanted it to be a problem, but there was a sense of 'well, wait a moment, it is not as simple as we a thought it is. You see something, you see yet something else - everybody sees something. If it is a huge problem or a tiny one - we don't know yet. But there is reason enough to go further with this debate'. Over ten years later this resulted in a European regulation which was then called REACH." (interview Meijer)

Thus, Meijer reports how he expounds the epistemic, as well as political, implications of a rather confidential assignment. Meijer sought for problems in order to go back to work with a problem worth solving. To maximize his chance of success, he decided to open the negotiations about a renewal of chemical risk regulation by an invitation for others to also disclose concerns, uncertainties and opposing standpoints. Accordingly, he describes the very definition of the problem as the result, not the starting point: "Thus, apparently there was a problem and apparently there was reason enough to do something about it. But in that very moment, I didn't know and the people didn't know either. The label REACH came out years later." (interview Meijer)

Implied in this disclosure is a chicken-egg question: is risk governance intrinsically problematic as a policy issue, or has it acquired those features by creation? According to the former head of the department, the policy was directed towards structural changes in the contemporary policy system, namely "a few simplistic ideas: responsibilities have to change, efficiency has to get twenty times better and the government has to take anoth- 
er role." However, he remarks: "I didn't have more than that to start with. How I would influence all that - at that moment, I didn't have a clue." (interview Brouwer). Using the metaphor of building a treehouse, also his colleague Meertens looks back on this initiation phase, in which there were no practical guidelines (interview Meertens). Hence, the policy itself was designed by means of a kind of phase zero that can best be called "articulation work".

In describing the further process, one interviewee involved emphasizes how the practice imports various, largely incompatible political cultures. This implies difficult social prerequisites, but also material requirements: The regulative principle at the outset was for industries to assign the chemical industries themselves with the responsibility to document and prove the safety of the used substances. According to Peter Meijer, that administrative goal demanded a certain empathy on behalf of the administrators:

"However, a good policy officer does not have to be the ultimate carpenter himself, but should be a very good instructor. He should know how timbering works so that he is able to understand and commission a carpenter who is sitting at an executive organization or an enforcement organization or in business." (interview Peter Meijer)

To remain in control despite this highly reflexive practice, the administrators working on SOMS decided to institutionalize a form of listening-in. Inspired by the British institution of round tables (interview Meertens), they installed so-called 'sounding boards' between representatives from the Dutch government, industries and environmental NGO's (Dutch: klankborden). On the strategic level, the advantage of sounding boards is that early brainstorming justifies later decisions by pointing at the original support or to the righteous means in coping with a problem (interview Meertens).

In retrospect the overall approach can be described as 'co-creative' since the material object of policy-making was defined and shaped at the same time and in combination with a wider collaborative collective. That approach, however, was soon challenged by a first hurdle.

In August 2000 the hitherto highly collaborative NGOs opposed the informal agreement on the legislation of chemical substances. Their subsequent withdrawal from the troika eventually broke the entire three-party arrangement, even though - as Meertens remarks - it was useful diplomatically to prove towards the industries how the government's demands are not uncompromising but actually risk another parties' loyalty (interview Meertens).

The NGOs insisted on an approval for the policy design by the Lower House. In March 2001 they addressed the parliament with a letter which describes the SOMS design as privatizing the power to verify the risk information which the industries were supposed to deliver (Waterpakt, Natuur en Milieu, Stichting de Noordzee, and Greenpeace Nederland 2001). In their opinion, governmental and public insight in the treatment of risky substances would be more or less a matter of industrial goodwill. In a phone interview, a representative of the NGO "Natuur en Milieu" argued that the informal agreement would have benefitted the industries' one-sided interests and undermined the government's responsibility towards the parliament (interview Veld).

The dropping out of the NGOs is one basis for the involved administrators to stress that multiple loyalties played a key role in the process. One interviewee says:

"Then you see - also with our industrial colleagues and others - that you are often tied to double loyalties. We were constantly having three, four loyalties you are living with bureaucrats, with economic affairs, with social affairs, with business and with environmental organizations to whom we were very akin, but who did have another sort of responsibility. With all these groups you entertain a form of loyalty." (interview Brouwer) 
In another interview, Brouwer's successor frames this conflict as inherent in the NGO's political cultures. By definition, he says in a tone of appreciation, "NGOs are visionary". However, while the government framed informal agreements as necessary, publicly desirable and mutually beneficial policy-making, the involved NGOs framed informal agreements bypassing democratic institutions, as "back room politics" (interview Veld). To conclude with regard to articulation work, I demonstrated that the launching of a project entails both formulation and formation of the problem at hand. At SOMS/REACH, the social and material formation of the project was actively entwined by Meijer and his colleagues who provoked and assembled diverging standpoints and thereby crafted the policy's first outline.

\subsection{The European Stage: Mutual Monitoring and Second Hurdle}

In March 2002, thus one year later, left-wing politicians picked up on the NGOs during parliamentary debates and called for a "stick behind the door", that is, for a backup instrument to enforce the provision of data in case the industries would not deliver what was promised (Parliamentarian Poppe, SP, Tweede Kamer, 2002: 4). At this moment, Minister Pronk admitted not to have such a measure as long as the new regulations would not take effect (Tweede Kamer, 2002: 8). In contrast - stirred by the industries' declaration of intentions - the Lower House's right wing required the minister to respect company secrets and fair competition (Tweede Kamer, 2002; Parliamentarian van den Akker, CDA). Thus, the minister was confronted with diverging expectations. Additionally, puzzled by an unexpected prohibition of the fire-retardant substance FR-720, the opposition asked for better adjustment with the slower European policy design, less hastiness and "island thinking" (Parliamentarian Udu, VVD; Tweede Kamer, 2002: 4).

Interestingly, the government in fact followed a double strategy as a later report on the progress with SOMS revealed (Haverland, 2008: 22). During the negotiations on the quick scans as a rather flexible and trust-based agreement, the government did in fact pressurize the industries in this collaboration by means of a sort of "stick behind the door" - just as the opposition previously demanded: the so-called 'registratiebesluit' i.e. registration decree. Although put on hold for two years under influence of the European Commission, the registration decree was used to threaten chemical producers and importers with external experts that would monitor and enforce particular risk categories and communication rules. Only in 2007 when on the European level REACH was ready to come into force, the registration decree was introduced in the Netherlands (Haverland, 2008).

For the public administrators, navigating the political heterarchy also involves a great temporal divergence between national and European policy arenas. Quite literally the parallel development on the European and Dutch stage enforced a balancing act on the group of Dutch administrators. Correspondingly, the administrators engaged in what can be called mobility work in the sense of coordination activity and balancing act. Or, as David Stark has it: "heterarchy is neither harmony nor cacophony but an organized dissonance." (Stark, 2011: 27)

During the launching of REACH, Meertens reports that opportunity structures were not just awaited but had to be tailored. On the one hand, there was a largely European tendency of Dutch policy discourse, during SOMS/REACH particularly launched by the (then) secretary of state of economic affairs Karien van Gennip: Regarding chemical policymaking, this argumentation previously had led to the abolishment of a national legislation, the so-called 'wet milieugevaarlijke stoffen' (WMS). On the other hand, this European expansion - "the turning-off of national minds" (Interview Meertens) - generally aimed at reducing the regulative constraints for European industries. According to Meertens, this tendency was threatening to overrun their plans for a new attempt to 
request industries to take responsibility themselves. However, by means of a trick best known as "strategic inversion", the administrators behind SOMS/REACH managed to use this constraining tendency to attain political weight. Meertens explains: "This threat we transformed into an opportunity by saying 'yes, we completely agree, but of course there should be a high level of protection, higher than it is now'. (...) Thus, constantly inversing things and different opinions - you can use that." (interview Meertens)

As time went on, the Dutch predecessor SOMS increasingly obtained a different political role, namely the role of a "think tank" merely inspiring and equipping the Dutch contributions in Brussels (all interviews, especially Peters). The Dutch administrators actively searched for alliances on the European level, for instance the directorates responsible for environment and industry, which - just as their Dutch equivalents - stood in a certain conflict.

"What we also did very consistently is to try playing chess on several boards at once (...). At a certain moment, we went as far as positioning one of our best people on that level - part-time in Brussels in order to support the Commission in the elaboration of the proposal. We invested in working door to door with the European Commission at our own expense - after all, we missed this capacity here. Some people, such as this man, worked day and night on formal as well as informal issues." (interview Brouwer)

This playing chess on several boards, for instance, implies phone calls from Brussels to The Hague with the request to silence colleagues in other ministries unnecessarily constraining the informal consultations on the European level (interview Brouwer). To conclude with respect to mutual monitoring, we have seen that, paradoxically, the administrators do not tackle the apparent 'wickedness' in any reductive manner. Political weight is acquired through jumping on remote bandwagon and maintained through coordinating across procedural phases and organizational boundaries. In mutual monitoring, for instance by combining strategic constellations across national and European policy levels, policy-makers across temporally and spatially diverging arenas find ways of aligning their work.

\subsection{Mobility Work and the Final Hurdle}

On the national level, the administrators exerted themselves for motivating the industries to support SOMS. They for instance invited the 'Association of the Dutch Chemical Industry', $\mathrm{VNCl}$, to give access to their rank and file within industries. This disclosure of networks would have opened an entire platform of companies to learn about their needs and problems (Interview Meertens; van Asselt has a similar remark with regard to $\mathrm{VNCl}^{\prime} \mathrm{s}$ lack of contact to the Dutch Permanent Representation; Marjolein Asselt et al., 2008). Despite this, eventually the Quick Scan methodology failed due to the following events.

As was noted before, the administrators kept on expanding the policy-related network notwithstanding the laborious efforts to keep it all together. $\mathrm{VNCl}$ however refused the request and relied on the European track of their double strategy for several reasons. According to the interviewed administrators, $\mathrm{VNCl}$ may have been too concerned of losing their representative function in the chemical sector. The Dutch group of policymakers nonetheless tried to expand their approach to the European stage. Yet from a European chemical industry perspective, SOMS threatened to present the Dutch Quick Scans as a fait accompli to the REACH negotiations, which were kicked off by means of the European White Paper from February 2001 (European Commission, 2001). VNCI more or less openly collaborating during the informal agreement of SOMS - was somehow pressurized by their European umbrella organization, 'European Chemical Industry Council' (short: CEFIC), to not undermine their European stance by signing in on the Quick Scan methodology (interview Peters). As Peters puts it, "VNCl found itself between 
the devil and the deep blue sea. On the on hand, they grew with our sort of thinking and saw its value. On the other hand, their big brother in Europe said 'you are not allowed to join in. If you break the unity in Europe we lose bargaining power'." (interview Peters) Thus, the continued co-creation of the legal framework was undermined by the industrialist power play on the European stage.

Meertens explains this breaking point as follows: The quick scan idea "was so to the point that plenty of law firms from entire Europe descended on us. The entire industry of Europe threatened with an assault on the Netherlands. They really pulled out all the stops to prevent that the Netherlands would go any further with this as it would ultimately disclose the poor state of affairs regarding the information about substances." (interview Meertens). As also a soap industry representative confirms, $\mathrm{VNCl}$ and CEFIC were worried that SOMS would result in too pragmatic measures:

"SOMS was so pragmatic that it was rapidly enforceable. Suppose it had become a fact, the Netherlands would have been able to implement it without the rest of Europe even wanting it. As the case may be, you see that CEFIC has done a lot to put off this process." (interview Kunst)

According to these interviews, the transparency and immediate applicability of the Quick Scans would have further complicated the European negotiations, for instance, by disclosing the overall shape of chemical risk regulation or by prematurely stigmatizing certain substances (Interview Meertens). Additionally, industries would have been responsible to conduct this critical registration themselves in the course of the Dutch idea of Quick Scans (interview Brouwer). Hence the chemical sector could rely on the European developments, where they had a more powerful and less publicly transparent influence on chemical substance regulation. In the eyes of the Dutch policy-makers, it is here where their mobility work failed: international lobbying, thus the mobility work of chemical companies, was a breaking point that undermined the "right configuration of people, resources, knowledge and place" (Bardram and Bossen, 2005: 189) on behalf of the Dutch policy-makers. As a result, the core piece of SOMS, the Quick Scans, was not implemented in REACH.

\section{Discussion: Co-Creation as 'Soft' Law Making?}

The genealogy from SOMS to REACH is a process of the Europeanization of risk governance. The notion of political heterarchy sheds light on a structural dimension in this process. SOMS and REACH were intended to reshape the communication channels as to make chemical companies responsible for risk assessment. This shift of responsibility has been coined a paradigm shift towards "responsive regulation" (Fuhr and Bizer, 2007). As a result, contradictory value systems, logics and hierarchies converge into a political heterarchy. Amidst this heterarchy, public administrators are in a difficult spot. Their practice even bears a 'chicken or egg' question: does the surrounding complexity - here deemed 'a political heterarchy' - impose the necessity for administrators to conceive of their work in a creative way?

On first sight, the empirical insight corresponds to this conclusion. The co-creation of SOMS by administrators in the Dutch environmental ministry eventually failed on the European stage. The process was killed by its own baby. Yet, the interviewed administrators were not victims, but co-creators of their heterarchic surrounding. The case study illustrates an immersive and proactive practice of policy-making. The interviewed administrators openly admit how the complexity of risk governance could have been circumvented by conventional policy instruments. Still, they chose to open and widen the collectives and conditions that influence what is conceived of as 'the problem'. One exem- 
plary interviewee even shows pride in being immersed in a political heterarchy that is less the subject, but the constitutional surrounding of policy-making:

"You can use the characteristics of the process as lessons for what you may do in the future. The way of organizing yourself, the way of playing out arguments, the way of using windows of opportunities which emerge; a less fragmented way of thinking - to think in broad contexts; to try to put yourself in the interests of others; the context of essential starting points for policy-making and the attempt to go along with that. Thus, transform yourself all the time!" (interview Meertens)

This quote presents public administrators as creative learners. Co-creation, for instance the co-creation of the Quick Scan methodology, in a material dimension is purposefully entangled with its social complexity, which in the presented case finally turned out to be fatal.

In a more encompassing aspect, the article pushes for a normative discussion. One may infer a deliberative ideal of governing. When the accountability for policy-making is not based on democratic principles alone but involved in a contradictory setting (cf. Brunkhorst, 1999), common problems cannot be solved by formal legislation alone according to Eriksen (ibid.: 6). A "'soft law"' (emphasis in original) is negotiated during a multi-actor dialogue.

However, the normative implication of SOMS/REACH is more tenuous. In line with Claus Offe's warning, the Europeanization of risk governance shows that " $\mathrm{t}$ )he vision of promoting policy convergence at the European level by very "soft" means is highly ambitious indeed, given the very "hard" facts of national differences and priorities" (Offe, 2002: 465). In SOMS/REACH the effort failed, due to the intensified lobbying on the European economic policy stage. On closer scrutiny, the empirical lesson is an inversed version of Offe's warning. A 'soft' co-creative approach in national political cultures was hampered by their recombination on the European level. Much more in line with Lepsius' characterization, "(t)he EU cuts specific situations out of the policy areas that in principle operate interdependently and subjects them to supra-national structuring requirements" (2000: 6). The case study reveals how the involvement of non-governmental stakeholders introduced a plethora of quality criteria and hierarchies that were at no point resolved, but rather maximized in both institutional complexity and normative ambiguity. This folding and unfolding of several logics makes it so difficult for "soft law' to be hardened so as to achieve the same level of bindingness as formal directives (...)" (Offe, 2002: 465). In that sense, the political heterarchy may even be a distinct feature of Europeanization, whereas "more (...) heterarchic governance does not mean automatically more participatory governance" (Smismans, 2008: 19).

\section{Conclusion: Europeanization as Heterarchization}

The creativity of public administrators can be seen as a blessing or a burden, and for better or worse, one has to realize that recent governance principles - for instance, "risk governance" and the "precautionary principle" inspiring SOMS/REACH - resonate with a proactive, enduring and literally expansive creativity on administrative work floors. Provisional politics is likely to yield improvising practices. However, those improvising practices cannot always be assumed to adhere to the normative principles of co-creation, neither in the process, nor in the result.

The case study reveals how the Europeanization of risk governance is a process of heterarchization. Dutch administrators previously involved in SOMS engaged heavily in European negotiations, thus operating amidst contradictory hierarchies and juggling with several loyalties and evaluative criteria. Eventually, in 2007, this trajectory led to what some call the European Commission's most complex bill so far (Rettman, 2007). With this case focusing on one of the central Europeanization processes, and interviewing a few 
extraordinarily reflexive policy-makers, I conclude with a few general remarks: Amidst a political heterarchy, co-creative processes face several challenges at once. They are likely to fail due to democratic processes that require a formalized accountability and representation of interest. Further, they are simultaneously likely to fail due to industry lobbying that preempts the policy to reflect co-creative principles. Yet, when co-creative policy-making is faced with several threats that continue to shape the Europeanization process - be it formal national democracy or informal international lobbying -, administrative creativity only increases in importance.

\section{References}

Van Asselt, M., and Renn, O. (2011). Risk governance. Journal of Risk Research, 14(4), 431-449.

Ayoub, N., and Batres, R. (2009). An approach to wicked problems in environmental policy making. WSEAS Transaction on Environment and Development, 5(3), 229-239. May 7, 2018. Retrieved from http://www.wseas.us/elibrary/transactions/environment/2009/28-927.pdf

Bach, M. (2008). Europa ohne Gesellschaft. Politische Soziologie der Europäischen Integration. Wiesbaden: Springer VS.

Ban, C. (1995). How Do Public Managers Manage? Bureaucratic Constraints, Organizational Culture, and the Potential for Reform. San Francisco: Jossey-Bass.

Bardram, J. E., and Bossen, C. (2005). Mobility Work: The Spatial Dimension of Collaboration at a Hospital. Computer Supported Cooperative Work (CSCW), 14(2), 131-160. doi: 10.1007/s10606-005-0989-y

Booher, D. E., and Innes, J. E. (2010). Governance for Resilience: CALFED as a Complex Adaptive Network for Resource Management. Ecology And Society, 15(3).

Brunkhorst, H. (1999) Heterarchie und Demokratie. In: Brunkhorst, Hauke und Niesen, Peter (Hg.), Das Recht der Republik, 373-385. Frankfurt: Suhrkamp.

Büttner, S. M., \& Mau, S. (2014). EU-Professionalismus als transnationales Feld. Berliner Journal für Soziologie, 24(2), 141-167.

Eriksen, E. O. (2007). Reflexive integration in Europe. ARENA Working Paper 04/20. May 7, 2018, May 7, 2018. Retrieved from http://www.sv.uio.no/arena/english/research/publications/arena-working-papers/20012010/2004/wp04_20.pdf

Fuhr, M., and Bizer, K. (2007). REACH as a paradigm shift in chemical policy - responsive regulation and behavioural models. Journal of Cleaner Production, 15(4), 327-334. doi: 10.1016/j.jclepro.2005.10.003.

Haverland, M. (2008). Schaken op meerdere borden De interactie van de Nederlandse overheid met het bedrijfsleven met betrekking tot SOMS en REACH. Erasmus. 
Heath, C., and Luff, P. (1992). Collaboration and Control. Crisis Management and Multimedia Technology in London Underground Line Control Rooms. Computer Supported Cooperative Work, 1(1-2), 69-94. doi: 10.1007/BF00752451

Hindmarsh, J., and Pilnick, A. (2002). The tacit order of teamwork: Collaboration and Embodied Conduct in Anesthesia. The Sociological Quarterly, 43(2), 139-164. doi: 10.1111/j.1533-8525.2002.tb00044.x

Ind, N., and Coates, N. (2013). The meanings of co-creation. European Business Review, 25(1), 86-95.

Jessop, B. (2002). The Future of the Capitalist State. Cambridge: Polity Press.

Kingdon, J. W. (2002). Agendas, alternatives and public policies. New York: Longman.

Lepsius, M. R. (2000). The European Union as a sovereignty association of a special nature. What Kind of Constitution for What Kind of Polity? In: 213. Jean Monnet Working Paper No.7/00. Cambridge, MA: Harvard Law School.

Lofstedt, R., Bouder, F., Wardman, J., and Chakraborty, S. (2011). The changing nature of communication and regulation of risk in Europe. Journal of Risk Research, 14(4), 409-429.

McCulloch W (1945) A heterarchy of values determined by the topology of nervous nets. Bull Math Biophys, 7:89-93

Mesman, J. (2012). Moving in with care: about patient safety as a spatial achievement. Space and Culture, 15(1), 31-43.

Ministerie van Sociale Zaken en Werkgelegenheid. (2011). REACH 2010. Hand in hand met Arbeidsomstandigheden. Den Haag. May 7, 2018. Retrieved from http://www.rijksoverheid.nl/documenten-

enpublicaties/rapporten/2011/09/19/factsheet-reach-2010.html

Ministerie van VROM. (2010). REACH komt, WMS gaat. Den Haag. May 7, 2018. Retrieved from

http://www.rijksoverheid.nl/documenten-en-publicaties/brochures/2010/11/23/reachkomt-wmsgaat.html

Ministerie van VROM (2004). Nederlands stoffenbeleid in internationaal perspectief. Uitvoeringsnota SOMS. Den Haag.

Noordegraaf, M. (2007). Men at Work. How Public Policy Managers Cope with Slow Processes in High-Paced Environments. In R. A. W. Rhodes, P. 't Hart, and M. Noordegraaf (Eds.), Up Close and Personal. Studying Government Elites (pp. 78-102). Basingstoke: Palgrave McMillan.

Offe, C. (2002). The European model of social capitalism: Can it survive European integration? The Journal of Political Philosophy. 11 (4), 437-469.

Peters, B. (2016). How not to network a nation: The uneasy history of the soviet internet. MIT Press. 
Rettman, A. (2007). EU's REACH chemicals law begins life in Helsinki. EU Observer. Brussels. May 7, 2018. Retrieved from http://euobserver.com/19/24169

Rhodes, R. A. W., 't Hart, P., and Noordegraaf, Mirko. (2007). Observing Government Elites: Up Close and Personal. Basingstoke: Palgrave McMillan.

Rip, A. (2006). A co-evolutionary approach to reflexive governance - and its ironies. In J.P. Voss, D. Bauknecht, and R. Kemp (Eds.), Reflexive governance for sustainable development (pp. 82-100). Cheltenham: Edward Elgar Publishing.

Rittel, H. W. J., and Webber, M. M. (1973). Dilemmas in a general theory of planning. Policy Sciences, 4(2), 155-169. doi: 10.1007/BF01405730

Van Ryzin, G. G. (2011). Outcomes, Process, and Trust of Civil Servants. Journal of Public Administration Research and Theory, 745-760. doi: 10.1093/jopart/muq092

Schuller, G. (1968). Early Jazz. New York: Oxford University Press.

Schmieg, G./ Meyer, E./ Schrickel, I./ Herberg, J./ Caniglia, G./ Vilsmaier, U./ Hörl, E./ Laubichler, M./ Lang, D. (2017): Modeling normativity in sustainability: a comparison of the sustainable development goals, the Paris agreement, and the papal encyclical. Sustainability Science (2017): 1-12.

Smismans, S. (2006). New Modes of Governance and the Participatory Myth, European Governance Papers (EUROGOV) No. N-06-01 http://www. connex-network. org/eurogov/pdf/egp-newgov-N-06-01. pdf.

Stark, D. (2001). Ambiguous Assets for Uncertain Environments: HETERARCHY IN POSTSOCIALIST FIRMS. In DiMaggio P. (Ed.), The Twenty-First-Century Firm: Changing Economic Organization in International Perspective (pp. 69-104). Princeton, Oxford: Princeton University Press. May 7, 2018. Retrieved from http://www.jstor.org/stable/j.ctt7rrcq.5

Stark, D. (2011). The sense of dissonance: Accounts of worth in economic life. Princeton University Press.

Strauss, A. (1988). The Articulation of Project Work: An Organizational Process. The Sociological Quarterly, 29(2), 163-178.

Suchman, L. (1997). Centers of Coordination. A Case and Some Themes. In L. B. Resnick, R. Säljö, C. Pontecorvo, and B. Burge (Eds.), Discourse, Tools, and Reasoning: Essays on Situated Cognition (pp. 41-62). Berlin: Springer-Verlag.

Smismans S. 2006. New Modes of Governance and the Participatory Myth, Report N-0601, European Governance Papers.

Tweede Kamer, der S.-G. (2001). Strategienota omgaan met stoffen. Vastgesteld door de ministerraad op maart 2001. Den Haag. May 7, 2018. Retrieved from https://zoek.officielebekendmakingen.nl/dossier/27646/kst-27646-

2 ?resultIndex $=19$ andsorttype $=1$ andsortorder $=4$ 
Tweede Kamer, der S.-G. (2002). Kamerstuk nr 10. Verslag van een algemeen overleg vastgesteld op 26 maart 2002. Den Haag. May 7, 2018. Retrieved from https://zoek.officielebekendmakingen.nl/dossier/27646/kst-27646-

10 ?resultIndex $=9$ andsorttype $=1$ andsortorder $=4$

Tweede Kamer, der S.-G. (2009a). Brief van de Minister van VROM aan de Voorzitter van de Tweede Kamer der Staten-Generaal, 2 april 2009. Den Haag.

Voß, J. P., and Bornemann, B. (2011). The politics of reflexive governance: challenges for designing adaptive management and transition management. Ecology and Society, 16(2).

de Vries, A., Halffman, W., and Hoppe, Rob. (2010). Policy Workers Tinkering with Uncertainty: Dutch Econometric Policy Advice in Action. In H. Colebatch, Robert Hoppe, and Mirko Noordegraaf (Eds.), Working for Policy (pp. 91-114). Amsterdam: Amsterdam University Press.

Wagenaar, H. (2004). "Knowing" the Rules: Administrative Work as Practice Introduction: Understanding. Public Administration Review, 64(6), 643-655.

Weber, M. (2006). Wirtschaft und Gesellschaft. Wirtschaft und Gesellschaft (Vol. 1999). Paderborn: Voltmedia.

Weick, K. E. (1998). Introductory Essay -Improvisation as a Mindset for Organizational Analysis. Organization Science, 9(5), 543-555. doi: 10.1287/orsc.9.5.543

Woldendrop, H. E., Swart-Bodrij, A., and Kwisthout, K.-K. (2007). REACH komt, de WMS gaat. De uitvoering van REACH in Nederland. Milieu and Recht, 34(8), 479-486.

Wynne, Brian. (2006). Public engagement as a means of restoring public trust in science hitting the notes, but missing the music? Community genetics, 9(3), 211-20. doi: $10.1159 / 000092659$ 